\title{
LINGUAL SEMIOTICS OF ABSOLUTE POWER IN THE TUDORS' TIMES
}

\author{
Tatyana N. Astafurova \\ Volgograd State University, Volgograd, Russia \\ Andrey V. Olyanich \\ Volgograd State Agrarian University, Volgograd, Russia
}

\begin{abstract}
The paper addresses the phenomenon of absolute power enablement in Great Britain of the $15^{\text {th }}-16^{\text {th }}$ centuries from the perspective of social semiotics and semantics: it includes the definition of obligatory and optional parameters of power and identification of its lingual-semiotic, ethno-cultural and semantic features. The Anglo-Saxon absolute power generates a lingual semiotic space that is structured with a system of verbal and nonverbal signs of various complexity and content; they perform their iconic, directive, evaluative and presentation functions to exercise maximum authoritative impact. Special attention is paid to royal rituals as the power is enabled through them. The case study reveals semiotic, ritual and nominative means of power representation in times of the royal dynasty of the Tudors (1485-1603), a period reputed as England's "Golden Age".

The semantic space of Anglo-Saxon absolute power is composed from lexical units that nominate subjects, objects, tools and resources of royal power (economic, social, political), as well as its authority actions, conditions and processes that depict the stages of «birth, life and death" of power in general and formation, distribution and enactment of power in England of the Anglo-Saxon era, represented by the specific conceptual and lingua-cultural sphere by means of non-verbal (material) and verbal signs.

Key words: absolute power, lingual semiotics, ritual component, chronosemiotic component, toposemiotic component, signs-regulatives, signs-processives, signs-classificators.

Citation. Astafurova T.N., Olyanich A.V. Lingual Semiotics of Absolute Power in the Tudors' Times. Vestnik Volgogradskogo gosudarstvennogo universiteta. Seriya 2, Yazykoznanie [Science Journal of Volgograd State University. Linguistics], 2017, vol. 16, no. 4, pp. 167-176. DOI: https://doi.org/10.15688/jvolsu2.2017.4.15

УДК $81 ’ 22$

ББК 81.002

Дата поступления статьи: 08.08.2017

Дата принятия статьи: 05.10.2017
\end{abstract}

\section{ЛИНГВОСЕМИОТИКА АБСОЛЮТНОЙ ВЛАСТИ ТЮДОРОВ}

\section{Татьяна Николаевна Астафурова}

Волгоградский государственный университет, г. Волгоград, Россия

\section{Андрей Владимирович Олянич}

Волгоградский государственный аграрный университет, г. Волгоград, Россия

Аннотация. В статье рассматривается феномен абсолютной власти в Великобритании XV-XVI вв. с позиций социальной семиотики и семантики: дается характеристика обязательных и дополнительных параметров власти, определяются ее языковая, семиотическая, этнокультурная и семантическая специфика. Показано, что англосаксонская абсолютная власть создает языковое семиотическое пространство в виде системы вербальных и невербальных знаков различной формы и содержания, которые актуализируют иконические, директивные, оценочные и презентационные функции для оказания максимального властного воздействия. Особое внимание уделяется королевским ритуалам, поскольку власть реализуется преимущественно благодаря им. Проведенное исследование выявило семиотические, ритуальные и номинативные средства 
оказания властного воздействия во времена правления королевской династии Тюдоров (1485-1603 гг.), период, известный как «золотой век» Англии.

Семантическое пространства англосаксонской абсолютной власти представлено лексическими единицами, номинирующими субъекты и объекты абсолютной власти, ее инструменты, ресурсы (экономические, социальные, политические), а также авторитарные действия, условия и процессы, которые отображают этапы «рождения, жизни и смерти» власти в целом и специфику ее формирования, распределения и удержания в англосаксонской Англии с присущими ей концептуальными и этнокультурными отличиями, обнаруживающимися в невербальных (материальных) и словесных знаках.

Ключевые слова: абсолютная власть, лингвосемиотика, ритуальная составляющая, хроносемиотическая составляющая, топосемиотическая составляющая, знаки-регуляторы, знаки-процессивы, знаки-классификаторы.

Цитирование. Astafurova T. N., Olyanich A. V. Lingual Semiotics of Absolute Power in the Tudors' Times // Вестник Волгоградского государственного университета. Серия 2, Языкознание. - 2017. - Т. 16, № 4. C. 167-176. - DOI: https://doi.org/10.15688/jvolsu2.2017.4.15

\section{Lingual semiotics of absolute power}

The semiotic interpretation of the phenomenon of absolute power is thoughtprovoking in several major respects. First, signs related to it strongly rely on cultural and social awareness of the interpreter within the particular context of Anglo-Saxon history of England. Second, verbal, as well as non-verbal signs, designating absolute power are various in their content, form and functions. Full complete representation of realia of absolute power contains both linguistic and extra linguistic units. There are words, phrases and speech acts that carry out symbolic functions, artifacts, colours, images, rituals, that may be interpreted as a sign.

In order to achieve the aims and depict the discourse of absolute power it is important to look at language signs through institutional and interpersonal relations that may be referred to a certain period of Anglo-Saxon history. Thus, social semiotics engaged in this work is a way to disclose social power communication features in the time of the Tudors backed up by sign vehicles embedded in social contexts. The relationship of language use, ideology and linguistic structures relies on referential projection, or objectification. Objectification refers to the forms through which the language structure is projected as the world structure. Language reflects cultural, social and political background, because it is a semiotic device, a signaling system, which is entrenched in these frames and limited by their contextual variables. It implies the use of the set of selections and meaning potential designed to build and shape social relations through semiotic resources of discourse.
Social semiotics is centered on social, cultural, political and historical study of meanings and is designed to discover the way people employ signs for building a community life. The enquiry into objectification of absolute power through the lens of social semiotics involves both the analysis of signs and different social meaning-making practices of all types, i.e. signs production modes, within the frames of humanities and social sciences. Meanings are not meanings of signs in themselves but are constructs made by participants in the community through repeated social practices and physical-material processes structured by and rooted in social semiosis. These encompass various types of semiotic content and forms linguistic, somatic, actional, pictorial, and other modalities and their coding fixations. The basic logic of social semiotics is contextualization.

The concept of absolute power is reflected in the holistic lingual semiotic picture of the world of Anglo-Saxons of the $15^{\text {th }}-16^{\text {th }}$ centuries in the processes of power enactment during the course of historical developments of Anglo-Saxon society. To investigate its comprehensive representation we had to systematize social, cultural and textual data on the formation and functioning of the Anglo-Saxon absolute power in the reported historical period, to detect the spectrum of motives, intentions and needs for power enablement in the Anglo-Saxons England, to exhibit its semiotic nonverbal and verbal spheres, to study the linguistic signs relevant for registered areas, extracted from the textual historical sources, as well as to consider information on the rhetorical strategies and tactics of monarchs, used to enforce their power.

Lingual semiotics of power is fixed in specific artifacts - symbols of mighty power. 
Items of power are the mascots of power, pointing to the hierarchical relationships in social reality, in large part stemming from interpretations of objects close to the authorities. For the Anglo-Saxon society the main figure is King (and his entourage), whose absolute power was most clearly manifested during the reign of King Henry VIII, who concentrated both secular and religious power in his own hands.

The term "regalia" is used for the nominations of signs and symbols of Royal power. Crown Jewels (regalia) are a stylistically designed unity. It is interesting that they are almost identical in all cultures, which indicates to their archaic nature. The Royal regalia are the Crowns, the scepter (with either the cross or the dove), the swords (of State, of offering), the King's orbs, maces, rings, spurs, the state flag, the state seal and national large shield. Regalia in a broad sense include also the throne, purple and other ceremonial royal robes. Royal regalia played an important role in the process of the power change, which was always tense, volatile and dangerous.

Peaceful transfer of power normally took place in the coronation. The coronation ritual had the meaning of providing legitimate and civilized transfer of power through magical artifacts. The coronation ritual developed, perfected and received its final form throughout the history of Anglo-Saxon statehood. At the coronation of Elizabeth II such royal regalia, as the sword of State, State seal, and State standards were used: it is these regalia that were always involved in coronation rituals, thus playing a stabilizing role in social processes (Queen Elizabeth's Coronation).

The most important attribute of power since ancient times has been personal arms. Wearing these, regardless of their possible use, is already a symbol of power as the ability to rule. Weapons demonstrate internal warlike nature of the ruler himself. After the coronation ritual actors went riding to the top of a hill and waved a sword on all four sides. This action symbolized readiness to fight the enemy, no matter whatever side he moved to the kingdom from.

An important representation of Royal power is the sovereign's orb, ball-shaped or globe-shaped, used as an old symbol of power, dominion over the World. The images of Roman emperors on the coins show that power as a symbol of imperial power was used in Ancient Rome: there were balloons depicted on the coins of Emperor Augustus, on which it was inscribed accordingly EVR (Europe), the ASI (Asia), AFR (Africa). Roman emperors frequently used a ball bearing the image of the goddess of victory, that later was replaced with a cross by Anglo-Saxon Kings.

Power is enabled through rituals. As parts of the rituals of the Anglo-Saxon power we distinguish chronosemiotic (temporal) and toposemiotic (spatial) components. As it is known, the ritual is one of the symbolic forms of conduct. Moreover, the ritual is the highest form and the most consistent embodiment of symbolism. The ritual presents the other side of things and phenomena which in everyday life are obscured, not visible, but in fact govern the true essence and purpose of being. Power gradually «settles» in the space of events and formalizes it according to presentation stages.

In the first phase the event flow attaches to the place of its actualization, the event becomes topologically fixed and determined. So, the main ritual of power transmittance is the royal coronation, which is traditionally held at Westminster Abbey (Royal Coronation Church). The coronation is an ancient ritual, which was used to confirm the legitimacy of the monarch's choice by the people, his sacrifice and consecration of his rule by God. A Coronation ceremony as a ritual dates back to 973 A.D. to King Edgar in the City Cathedral of Bath: "to establish his throne not only on the right of conquest or papal benediction, but on the support of the sacred hallowing which coronation would give him" (Hall).

In the second phase the event flow is defined by the limits beyond which certain symbols and signs lay down, which give the splendor of triumphal ceremonies of power (coronation, inauguration, initiation): symbols of power, plenty of gold jewelry, weapons, beautiful and expensive robes, chariots, horses decorated with flowers inform the society of power and wealth of the monarch, his talent of a warrior and a statesman.

In the third phase: the course of events is regulated, the repertoire of the activities and actions that make up the event or accompany it are defined; rules of events development are introduced and procedural constraints are imposed; a role event structure - participants and their roles - is stipulated. 
The rules of the coronation of Henry VIII and Catherine of Aragon (24th June, 1509) attached particular importance to the chronosemiotic component of the ritual, as Sunday is a religiously significant day for AngloSaxon flock, and Midsummer's Day is a sacred celebration of the summer solstice, tied with the ancient rituals and especially adored by AngloSaxons. The beginning of the ceremony was strictly fixed (at the appointed hour); in accordance with the rules of the ritual, the coronation was attended by courtiers of the right protected by their Ordinances, historical precedents and special privileges (the barons of the Cingue Ports); the higher clergy (the archbishop of Canterbury, the prelates of the realm); nobility and most distinguished citizens (the nobility and a large number of civic dignitaries), who were allocated places according to their status: "Each noble and lord proceeded to his allotted place the pre-arranged earlier according to seniority" (Hall).

Such important elements of the ritual, as the anointing of the throne and the coronation, were produced by the highest hierarch of the Church of England - Archbishop of Canterbury and the higher clergy: "His grace and the queen were anointed and crowned by the archbishop of Canterbury in the presence of other prelates of the realm" (British Historical Documents).

The coronation ritual also included the toast part, the semiotics of which was abundantly marked by signs of a hierarchical power structure: "the lords spiritual and temporal paid homage to the King and, with the Queen's permission, returned to Westminster Hall - each one beneath his canopy - where the lord marshal bearing his staff of office all ushered to their seats" (British Historical Documents).

The toposemiotics of the coronation ritual was manifested in the following:

- the strict fixation of the location of its members at the table during the ceremonial meal: "The ninepiece table set with the well-being of the King's estate seated on the right and the Queen's estate on the left" (Life in Elizabethan Period);

- deliberate decorativeness and vastness of space, through which the meal process flowed; these toposemiotic components stressed the magnitude and power of sovereign authority.
The sound-semiotic part of the ritual stressed a solemn key of power action and marked its sequence of stages. So, the coronation was accompanied by a choir singing prayers and hymns of the Church; serving of each dish in a lush feast was enunciated by the sounds of trumpets. Ritual actions changed by special sound signals, informing people about the monarch's accession to the throne: "There was a firing of guns and chamber music between 4 and 5 o'clock; by 6 o'clock began the proclamation of the Queen, with two heralds and a trumpet blowing" (Life in Elizabethan Period).

At the fourth stage the verbalization of a ritual event is carried out, the language component is clarified, the dependence of the success of the event from its verbal substantiation is established. It is believed that in the ritual communication nonverbal signs dominate over verbal signs. At the same time, being truncated, the verbal component is a central element of the coronation procedure under its rules. So, the oath of Elizabeth I to take care of her subjects and the prosperity of the Kingdom is laconic, but it passes the whole meaning of the ritual in a concentrated form - to use the supreme power given by God for the benefit of citizens and the whole Kingdom: "And whereas your request is that I should continue your good lady and be Queen, be ye ensured that I will be as good as you ever unto the Queen was unto her people. No will can lack in me, neither do I trust there shall lack any power. And persuade yourselves that for the safety and quietness of you all I will not spare if need be to spend my blood. God thank you all" (Carpenter, 1998, p. 16).

The oath of allegiance to the monarch was formulated by subjects in the coronation ritual process as an answer to the question of recognition of the monarch: The Recognition Question: "Will you take this most noble prince as your king and obey him with great reverence, love and willingness?" and the Reply to the Recognition Question: "Yea, Yea!" (Carpenter, 1998, p. 24).

No deviation was allowed in the verbal part of the coronation ritual, even of a procedural nature, while reading the canonical biblical texts accompanying the coronation of powerful persons. The verbal properties of the coronation speech of the monarch are the overbearing 
directivity, the markers of which are discursive elements: desire, demand that you will be faithful to, to be assistant to, make a good account to, to govern for the greatest wealth, to leave comfort to our posterity on earth, etc.; "I shall desire you all, my lords, (chiefly you of the nobility, everyone in his degree and power) to be assistant to me that I, with my ruling, and you with your service, may make a good account to Almighty God and leave comfort to our posterity on earth" (Reputedly spoken by Elizabeth I at her coronation) (Carpenter, 1998, p. 38).

At the time of taking an oath from the subjects, the monarch uses directive constructions as a tool of trust and favor: "This judgment I have of you, that you will not be corrupted by any manner of gifts, and that you will be faithful to the State; and that without respect of any private will, you will give me the counsel you think best" (Elizabeth to William Cecil on making him Secretary of State at her accession) (Life in Elizabethan Period). During the coronation, the monarch makes it clear, that power is concentrated in his hands - the power to rule and punish. Therefore, among the verbal signs of the coronation one can detect discursive elements indicating threat: "Let this my discipline stand you in good stead of sorer strokes, never to tempt too far a Prince's patience»; "Those who touch the scepters of princes deserve no pity" (Henry VIII's Act of Supremacy).

The absolute subordination to the monarch is viewed in the ritual of the oath of allegiance, which the head of the Privy Council pronounces first. So, swearing an oath by Lord Burghley, Chancellor of Elizabeth I, to the Queen in 1570 is characterized by ritualistic format provided by directivity:

- modality (you shall / shall not; if any treaties or councils shall),

- discursive formulas (you shall swear, you shall keep secret, you shall not reveal, you shall not let, you shall bear faith and true allegiance, you shall assist and defend, you shall do as a faithful and true councilor, etc.),

- attributive characteristics of the highest loyalty (to the utmost, uttermost, at all times, in all things, true, faithful, affection).

And, finally, the last feature of the verbal component of ritual discourse that we mark turns out to be its secondary nature, since the meaning and communicative tasks of power rituals are reflected in verbal discourses of their observers (The account at right was written by the Tudor chronicler Edward Hall), reminiscences and memoirs of the participants and witnesses: "How can I describe the abundance of fine and delicate fare prepared for this magnificent and lordly feast, produced both abroad and in the many and various parts of this realm to which God has granted his bounty" (Hall).

At the fifth phase the status of the spectacle is attached to the event: in order to affect the emotions of society, it must be visually expressive and emotively charged. The event is dramatized and acquires performance features, that is, it is being theatricalized for the maximum impact on society [Olyanich, 2004]. Ritual communication is often characterized by theatricality. Under its influence not only cultural, but also ritual power exercising activities are conducted. Thus, King Henry III during the reconstruction of the Norman Abbey made architects build a theater stage, where the coronation had to take place (Carpenter, 1998). Such an important ritual for the state, as the coronation of power elite, was inevitably subjected to directing and reenactment. According to witnesses of the coronation of Elizabeth I, festive performances began in different parts of London the day before the coronation ceremony. Each performance (spectacle, pageant) was carefully thought out and staged, and had its specific symbolic meaning. It was staged before the residents of the capital to clarify the essence of the future rule of the queen.

So, the first performance reminded people of Queen's English origin, as opposed to the Spanish roots of Mary and her husband King Philip, as well as her close relationship with Henry VII, who put an end to the Thirty Years' war. The actors made clear to the public, that the granddaughter of the one, who stopped the War of Roses, would unify England and give peace to it: "The first pageant laid out Elizabeth's genealogy, stressing her 'Englishness' (as opposed to the 'Spanishness' of Mary, who was half Spanish, and Philip, who was Spanish), and her descent from Henry VII and Elizabeth of York, whose marriage had put an end to years of civil war. The pageant made clear the implication that the granddaughter of those who ended the War of Roses would 
herself reunify England and bring peace to $i t$ " (Queen Elizabeth's Coronation).

The second pageant associated the future reign of Elizabeth with four virtues - true faith, love for subjects, wisdom and justice, that defeated the evil, embodied in prejudice and ignorance: "The second pageant showed Elizabeth's government characterized by the four virtues of True Religion, Love of Subjects, Wisdom and Justice trampling their opposite vices, including Superstition and Ignorance" (Queen Elizabeth's Coronation).

During the third performance the LordMayor gave an item, made of gold, to Elizabeth, which symbolically demonstrated the unity of the capital and the Crown: "During the third pageant the Lord Mayor presented Elizabeth with a gift of gold, symbolically demonstrating the interdependence of the City and the Crown" (Queen Elizabeth's Coronation).

In the fourth spectacle the prosperous Kingdom (of Elizabeth) was opposed to the destroying kingdom (of Mary). The main actor was the Truth, which gave the Queen the Bible with an inscription in English «word of truth». The Queen, accepting the gift, kissed the Bible and applied it to her breast, and the crowd made loud cheers: "In the fourth pageant, a decaying commonwealth (Mary's) was contrasted with a thriving one (Elizabeth's). It featured the figure of Truth, who was carrying a Bible written in English and entitled the Word of Truth. The Truth of the Bible presented to the Queen, who kissed it and laid it on her breast to the cheers of the crowd" (Queen Elizabeth's Coronation).

The fifth show predicted a long and prosperous reign of Elizabeth: the latter was depicted in the guise of Deborah-the-Prophet from the Old Testament, who saved the House of Israel and then ruled for forty years: "The task ahead of her was presented in the final pageant, with Elizabeth portrayed as Deborah, the Old Testament prophet, who rescued the House of Israel and then went on to rule for 40 years" (Queen Elizabeth's Coronation).

Presentation efficacy of these performances was huge: the combination of signs, involved in the theatrical action, successfully promoted such characteristics of the Queen, as the greatness of Elizabeth's status and royal dignity, coupled with the ease of communication, and this found hail in the hearts of city dwellers, who loved her: "Elizabeth excelled in the starring role in such spectacles, managing gracefully to combine the dignity and grandeur of her position with a common touch that allowed the public to warm to her. The procession was basically a popularity contest and it was a resounding public relations success for the new queen" (Queen Elizabeth's Coronation). Thus, it is through a reenactment, that people accepted their monarch the day before the coronation itself: "She emerged from the ceremony to greet her adoring fans wearing a big smile, her crown and carrying the orb and scepter of her new office" (Queen Elizabeth's Coronation).

Finally, at the sixth stage over time the event is exempt from a number of its components, minor essential in terms of impact, and is repeated in an altered form, i.e. all those components that have stood the test of time, with new elements, obtaining socially meaningful emotive potential to the maximum.

Another - lingual semiotic - way of rearrangement of the Coronation ritual is associated with the gradual replacement of the ritual language from Latin to English. The Coronation of William the Conqueror was conducted in English and French on Christmas Day, 1066. Later the ecclesiastical language for the Coronation became Latin, and only Elizabeth I was a staunch supporter of the compromise of Government decisions: "The ritual itself was a clever compromise between the Catholic practices that existed and the Protestant ones that she intended to introduce" (Queen Elizabeth's Coronation), and it was important for her to gradually displace the Catholic faith by the Protestant faith: "The changes in the service were a portent of the religious settlement to come and symbolic of her'make-haste-slowly' approach to introducing change" (Queen Elizabeth's Coronation). She insisted on conducting the coronation in two languages Latin and English: "She was crowned in Latin by a Catholic bishop but parts of the service that followed were read twice - in Latin and English" (Queen Elizabeth's Coronation). Subsequently, Latin was completely ousted from the coronation ritual, and replaced with British English as the national language. 
Thus, within the ritual space of Anglo-Saxon power throughout the history of power discourse an extensive and tightly fixed system of signs and symbols was formed that implemented the function of visual presentation of conventional agreement on the interaction between the sovereign and his subjects, supported by verbal signs of the appropriate ritual nature. We believe that there are three broad groups of signs that nominate the communicative situation, typical of Anglo-Saxon ritual power communication. This communicative situation reflects the affiliation of actors to social conventions and performance of sequence of identification rules required by the convention. The signs that nominate the communicative situation and emerge in a system are (1) signs-regulatives, (2) signs-processives, and (3) signs-classificators.

1. Signs-regulatives are signs that determine the conventional success of the situation of ritual communications within Anglo-Saxon power discourse.

1.1. The first sub-group signs define the participants of the ritual (signs-personalia). In Anglo-Saxon power discourse these are titles and forms of address to each of the groups in the ruling hierarchy - sovereigns (His Majesty the King, Her Majesty the Queen, Prince, Princess, His Highness, Her Highness), their noble family (Duke, Duchess, Marquis, Marchioness, Earl, Countess, Viscount, Viscountess, Baron, Baroness, Knight), the titles of the subjects (Lord Councilor), and hierarchs of the Church (the Archbishop of Canterbury, His Grace).

1.2. Signs of the second subgroup regulate the amount and sufficiency of participants of the ritual (signs-quantifiers). This is a fixed set of signs known in society as the nomination of the never-changing assembly of participants in the ritual. So, five barons of the five most significant for Crown Lands took part in the Coronation of Henry VIII (The barons of the Cingue Ports), and that marked the beginning of a tradition: the heirs of these barons have to be present at every subsequent coronation of British monarchs.

1.3. Signs of the third sub-group attach to the parties and nominate a symbolic toolkit (insignia), used in the ritual (signs-symbols). An important component of the semiotic Anglo-Saxon power is the color (The King's Colours) that nominates Royal symbols through the flags, standards and their other varieties (guidon, standard, vexillum, labarum, gonfalon, banner, banneret, banderole, oriflamme). To this subgroup one can refer ritual objects of royal authority (The Crown, The Orb, The Sceptre) and signs of belonging to the ancient family of rulers (The Coat of Arms, The Sovereign's Shield).

2. Signs-processives in the semiotic system of ritual events nominate and characterize the ritual actions and deeds of partakers. The processives include rigid structuring of the ritual from the beginning to the end. This group of signs also performs a regulatory function (each participant in the ritual is required to act in accordance with conventional rules of conduct and specific roles assigned to participants).

3. To the group of signs-classificators we refer the signs that: a) direct ritual communication in the right direction systematically towards the completion of a specific phase, and b) specify the behavior of participants of the ritual in a manner consistent with their social status or national origin. These are signs, marking the boundary of ritual phases (hymns, the Bell ringing at the beginning and at the end of the church service, in the climaxes of the coronation event, the standing up and leaning a head at the appearance of a powerful person.

\section{Semantics of absolute power}

The lexico-semantic space of Anglo-Saxon absolute power is highly represented by units that nominate subjects, objects, tools and resources of power, as well as authority actions, conditions and processes that depict the stages of «birth, life and death" of power in general.

Holders, or subjects of royal power are represented by such lexical units, as a king, queen, rex, regina, sovereign, monarch.

Objects of royal power comprise the hierarchy of personalities that exhibit a number of levels of approximation to the throne of the monarch:

1) the first level is reflected by the words: prince, princess, duke, grand duke, archduke, duchess that denote persons, close to sovereigns by blood and family ties;

2) the second level is represented by lexemes count, countess, baron, baronet, baroness, marquis, marquess, marchioness, 
earl, viscount, viscountess, knight, lord, dame, $l a d y$, etc., that nominate titles and ranks, given by the sovereign to vassals and their families as noble privileges by birth;

3) the third level are the names for secular, judicial, military and religious positions of royal subjects, to whom the sovereign delegates responsibility of authority - councilor, sheriff, marshal, archbishop, bishop, prelate, archdeacon, etc.;

4) the fourth level consists of lexical items, naming people, who catered to the sovereign and his court - lady in waiting, maid of honour, personal attendant, valet, master of ceremonies, master of heraldry, etc.

Instruments of power in the Anglo-Saxon governmental space are represented by lexical units, verbalizing means and methods by which absolute power was gained, expressed and held. First of all, these are the names that denote the documents related to the enforcement process in general: prescript, decree, edict, act, rescript, ordinance, ultimatum, verdict, injunction, statute, mandate, query, request, petition, bill, solicitation, precept, order, command, dictate. The lexical unit article occupies a special place in this row, denoting the consolidation of royal power with the spiritual power, successfully completed with the formation of the Anglican creed - Thirty-Nine Articles.

Power resources are an important part of the entire power process: their overbearing regulation and allocation is the real object of power manifestation. The resources of power include those material objects and spiritual benefits that, first, can meet the needs and interests of the people, providing some value in social relations and, second, increase the potential of influence and the strength of impact of power subjects. The most important social cause of the subordination of some people to others is the uneven distribution of resources.

Power resources vary and fall into utilitarian, enforced and regulatory units: the utilitarian are material social benefits; enforced - criminal and administrative measures of coercion; regulatory means of pressure on the inner world, value orientations and norms of human behaviour. They are designed to ensure the approval of the actions of the acting subject of power, compliance with the demands. The typology of resources may be carried out in accordance with the essential areas of activity (economic, social, political, security and informational).

The Anglo-Saxon absolute power is characterized by the following resource categories nominations:

- economic, in the form of gifts of land and royal subsistance, exemption from taxes and military service, wedding and funeral grants (inheritance on payment, the entire knight's'fee', the land entrusted, the land granted, 'release from the scutage', a reasonable 'aid', etc.);

- social, such as titles, ranks, rewards, orders (posts and positions in the office, privileges; freedom grants, ranks and titles; The Order of the Garter; The Order of the Bath; The Order of Merit; The Order of the Golden Fleece);

- political and power exercising - in the form of secret councils, courts, sheriffs, Army, Navy, guard subordinate to the King (Privy Council, courts, the army, fleet, navy, guard);

Power actions, states and processes are nominated by verbs, which form a special area of the lexical nominations of the Anglo-Saxon power space. Their semantic structure most clearly represents the rich palette of actions, states and processes at all stages of the life of absolute power and is reflected in markers of "power": authority, force, influence, might, power, right, strength. These stages acquire differential attributes in the semantic content of lexemes, comprising four lexical-semantic groups (LSG) of verbal power nominations - «Gaining power», «Manifestation of power», «Retention of power" and the "Overthrow of power" [Annenkova, 2005].

The dominant feature of the $\mathrm{LSG}_{1}$ "Gaining power" is a lexeme 'establish' to introduce and put a law into force; to make a state institution of (a church), the value of which in the most general way relates the procedure of gaining power, which is detailed through the combination of semantic attributes "peaceful::forceful", "legitimate::illegitimate", "explicit::hidden».

So, a peaceful procedure of gaining power is nominated by verbs: authorize 'to grant authority or power to; attain 'to succeed in obtaining authority or power'; constitute 'to set up or establish according to law or provision; en/crown 'to put a crown or garland on the head of; to invest with regal power; en/throne 'to 
invest with sovereign power or with the authority of high office'; heir 'to inherit or be entitled by law or by the terms of a will to inherit the estate of another'.

The forceful getting hold of power is reflected in semantics of arrogate 'to take or claim for oneself without right; usurp 'to seize and hold the power or rights of another by force; conquer 'to defeat or subdue by force, especially by force of arms'; oust 'to take the place of, esp. by force'; vanquish 'to defeat, subdue by superior force, as in battle'; subjugate 'to bring under control; to make subservient'.

Latent /covert power gain is revealed in the semantics of the following verb lexemes: supplant 'to usurp the place or position especially through intrigue or underhanded tactics; influence'; encroach 'to take another's possessions or rights gradually or stealthily'.

The apparent /overt acquisition of power, on the one hand, correlates mainly with peace and is represented in the semantics of the lexical units: en/crown 'to put a crown or garland on the head of; en/throne 'to invest with sovereign power or with the authority of high office'; heir to inherit or be entitled by law or by the terms of a will to inherit the estate of another'.

Legitimate and illegitimate power gain in verb lexemes correlates with the differential features - peaceful and forceful: appropriate 'legislate for some specific purpose or use'; claim 'to demand a legitimate or asserted right on something'; special 'to establish according to law or provision; institute 'to establish, organize, and set in operation; invest in an office or a position'.

The dominants of $\mathrm{LSG}_{2}$ "Manifestation of power" are the lexemes: rule 'to exercise control, dominion, or direction over; command 'to direct with authority; give orders to; to have control or authority over; rule. Their semantics covers a variety of powerful actions of the monarch with diverse resources of power: privileges, statutes, property. This group is the largest of the verbal LSGs, denoting power. It includes lexemes, representing legitimate and illegitimate, peaceful and forceful, overt and covert actions of Anglo-Saxon sovereigns in all spheres of public life, including the religious one: conscribe 'to draft for military or naval services'; consecrate 'to declare as sacred (a church); dominate 'to control, govern, or rule by superior authority or power; subject 'to submit to the authority'; tyrannize 'to exercise absolute power; to rule as a tyrant'; venerate 'to regard or treat royal persons with reverence'; worship 'to honor and love as a deity; to perform ceremonies, prayers, or rituals by which devotion is expressed.

$\mathrm{LSG}_{3}$ "Retention of power" comprises verbal lexical units, the semantic content of which primarily reflects the violent (penitential and suppressive) ways of absolute power to deal with dissent and opposition. Semantic dominants are lexemes: punish '(law; religion, military) to subject to a penalty for an offense, a sin, or a fault' и execute 'to put into effect measures worked out by authorities; to put to death, especially by carrying out a lawful sentence'.

Penitential, repressive and punitive semes (abolish, fine, penalty, burn, destroy, nullify, annul, deprive land ownership) are identified in the following verb categories: abolish '(law; monarchy) to do away with; abrogate 'to abolish, do away with, or annul, esp. by authority'; behead 'to punish by separating the head according to the decision of court'; exile 'to enforce law or sovereign offender's removal from his native state; exterminate 'to get rid of by destroying completely; extradite 'to give up or deliver (a fugitive, for example) to the legal jurisdiction of another government or authority'; incinerate 'to cause to burn completely (esp. in case of disobedience)'; oppose 'to be in contention or conflict with power; oppress 'to keep down by severe and unjust use of force or authority'; overawe 'to control, influence, subdue by inspiring awe or fear.

Finally, verbal lexemes of $\mathrm{LSG}_{4}$ "Overthrow of power" nominate procedures of the loss of power which, in the same way as a token with a total value of "Gaining power», correlate with a combination of semantic attributes "forceful::peaceful", «legitimate::illegitimate", "explicit::hidden". This group includes the verbs: abdicate 'to power officially relinquish without resistance'; restrain 'to deprive of freedom or liberty; keep under control'; deprive 'to remove from office'; dismiss 'to direct or allow to leave; to end the employment or service of; discharge; extirpate 'to destroy totally'; extradite 'to give 
up or deliver to the legal jurisdiction of another government or authority'.

\section{Conclusions}

Thus, the paper is in line with the complex social semiotic approach to the study of lingual and semiotic aspects of absolute power. The study is limited to the timing of the Tudors (1485-1603). This period appears as the era of the deepest and most important transformation processes in the development of absolute power that influenced the lingual semiotic picture of formation, distribution and enactment of power in England of the Anglo-Saxon period and its representation by means of non-verbal (material) and verbal means. A significant feature of this era is the establishing character of manifestation of absolute power signs in the Anglo-Saxon conceptual and lingual cultural sphere. The scientific novelty of the research lies in the fact that it is the first retrospective complex exploration of the historicalcultural, conceptual, language and speech processes that contributed to the design of the Anglo-Saxon absolute power; the first time the complex of language and non-language sign systems of the Tudors power enactment have been studied together; the first analysis of semantics of nomination of Anglo-Saxon absolute power has been performed.

\section{REFERENCES}

Annenkova O.V., 2005. Lingual and cultural characteristics of Anglo-Saxon power discourse: abstract of PhD thesis. Volgograd. 24 p. (in Russian).

Olyanich A.V., 2004. Presentation theory of discourse. Volgograd, Paradigma Publ. 507 p. (in Russian).

\section{SOURCES}

British Historical Documents. URL: www.bhd.org. Carpenter D., 1998. The Westminster Abbey. London, Harper. $48 \mathrm{p}$.

Hall, Ed. The Oxford Companion to British History. URL: http://www.encyclopedia.com.

Henry VIII's Act of Supremacy. URL: www.wikipedia.com. Life in Elizabethan Period. URL: www.dm.net.

Queen Elizabeth's Coronation. URL: www. maritimegreenwich.com.

\section{Information about the Authors}

Tatyana N. Astafurova, Doctor of Sciences (Philology), Professor, Department of Foreign-Language Communication, Volgograd State University, Prosp. Universitetsky, 100, 400062 Volgograd, Russia, pic@volsu.ru, https://orcid.org/0000-0002-1299-8109

Andrey V. Olyanich, Doctor of Sciences (Philology), Professor, Department of Foreign Languages, Volgograd State Agrarian University, Prosp. Universitetsky, 26, 400002 Volgograd, Russia, aolyanich@mail.ru, https://orcid.org/0000-0003-3990-5707

\section{Информация об авторах}

Татьяна Николаевна Астафурова, доктор филологических наук, профессор кафедры иноязычной коммуникации, Волгоградский государственный университет, просп. Университетский, 100, 400062 г. Волгоград, Россия, pic@volsu.ru, https://orcid.org/0000-0002-1299-8109

Андрей Владимирович Олянич, доктор филологических наук, профессор кафедры иностранных языков, Волгоградский государственный аграрный университет, просп. Университетский, 26, 400002 г. Волгоград, Россия, aolyanich@mail.ru, https://orcid.org/0000-0003-3990-5707 